\title{
Keragaman Sekuen Gen Reseptor Hormon Pertumbuhan Exon 10 sebagai Informasi Dasar Seleksi pada Sapi Pesisir Plasma Nutfah Sumatera Barat
}

\section{Single Nucleotide Polymorphism of Growth Hormone Exon 10 as Basic Information for Selection on Pesisir Cattle Germplasma In West Sumatera}

\author{
Yurnalis dan Sarbaini \\ Fakultas Peternakan Universitas Andalas, \\ Kampus Unand Limau Manis Padang, 25163 \\ E-mail :yurnalisunand@yahoo.com \\ (Diterima :13 November 2013; Disetujui: 09 Februari 2014)
}

\begin{abstract}
ABSTRAK
Dari 216 ekor sapi Pesisir berusia 1,5 tahun , 60 ekor dipilih berdasarkan berat badan, 30 ekor dengan bobot tertinggi $(125 \pm 9 \mathrm{~kg})$, dan 30 ekor dengan bobot badan rendah $(65 \pm 6 \mathrm{~kg})$. Keragaman gen reseptor hormon pertumbuhan (GHR) dilihat dengan sekuensing (SNP) dan dengan PCR - RFLP. Lima delesi terdeteksi di posisi 34, 39, 45, 50, dan 115 dengan frekuensi alel berturut-turut $0,45,0,15,0,46,0,46$, dan 1,00 dan 4 insersi terdeteksi di posisi 67, 74, 113, dan 133 dengan frekuensi alel berturut-turut $0,19,0,19,0,25$, dan 0,45 masing-masing dengan genotip insersi T , A , G , dan G. Empat mutasi terdeteksi di posisi 32, 50, 109, dan 150 dengan genotip $T$ $\rightarrow C, G \rightarrow A, A \rightarrow C$, dan $G \rightarrow C$ dengan frekuensi alel 0,50, 0,23, 0,19, dan 1,00. GHR-NlaIII alel $\mathrm{T}$ dan $\mathrm{C}$ masing-masing adalah 0,017 dan 0,983 . Uji chi-square menunjukkan bahwa populasi ini tidak dalam keseimbangan Hardy - Weinberg. Temuan ini menunjukkan bahwa GHR-NlaIII tidak dapat digunakan sebagai penanda untuk keturunan Bos indicus. Tidak ada hubungan antara keragaman gen GHR dengan dua kelompok ternak. Hasil penelitian ini menunjukkan bahwa gen GHR bersifat polimorfik sehingga perlu dicari hubungannya dengan performance dan pertumbuhan ternak.
\end{abstract}

Kata kunci : Sapi Pesisir , GHR, PCR - RFLP , SNP dan polimorfisme

\section{ABSTRACT}

From a total of 216 of 1,5 year old Pesisir cattle,60 were selected on the basis of weight, were 30 with highest weight $(125 \pm 9 \mathrm{~kg})$ and 30 with lower weight $(65 \pm 6 \mathrm{~kg})$. The sample were genotyped for growth hormone receptor (GHR) gene by sekuensing (SNP) and polymerase chain reaction-restriction fragment length polymorphism (PCR-RFLP). Five deletion were detected in position 34, 39, 45, 50, and 115 with frequency allele were 0.45, 0.15, 0.46, 0.46, and 1.00 respectively and 4 insertions were detected in position 67,74, 113, and 133 with frequency allele were $0,19,0.19,0.25$, and 0.45 respectively with the genotypes insertion $T, A, G$, and G. Four mutation were detected in position 32, 50, 109, and 150 with genotypes $T \rightarrow C, G \rightarrow A, A \rightarrow C$, and $G \rightarrow C$ respectively with frequency allele were $0.50,0.23,0.19$, and 1,00 respectively. The GHRNlaIII gene frequencies for the T and C allele were 0.017 and 0.983 respectively. The chisquare analysis indicated that this population was not in Hardy-Weinberg Equilibrium status. This finding showed that GHRNlaIII was not favorable as a GHR marker for Bos indicus breeds. There was no relationship beetwen variability and two group of cattle with these marker. These data provide evidence that GHR gene was good polymorphic source and can be used for association with performance and investigate whether this polymorphic might be responsible for quantitative variation in growth.

Keywords: Pesisir cattle, GHR, PCR-RFLP,SNP, polymorphism 


\section{PENDAHULUAN}

Peternakan sapi potong Indonesia sangat memprihatinkan karena ketergantungan terhadap ternak import yang semakin tinggi. Hal ini dikarenakan konsumsi tidak sebanding dengan pertumbuhan produksi ternak dalam negeri. Upaya untuk memenuhi kebutuhan dalam negeri telah mengarah kepada pengurasan ternak dan pemotongan ternak produktif, sehingga angka pertumbuhan ternak menjadi negatif. Tantangan kedepan adalah bagaimana mengurangi import ternak secara bertahap dengan kebijakan dan program yang memacu produksi ternak lokal. Untuk menumbuhkan dan memperkuat agribisnis ternak lokal ditunjukan pada dua aspek yaitu peningkatan reproduksi dan pertumbuhan ternak.

Sapi pesisir sebagai suatu plasma nutfah Indonesia diduga telah mengalami penurunan genetik yang disebabkan seleksi alami telah berjalan kearah negatif, dimana ternak yang dipertahankan untuk dipelihara adalah ternak yang berat tubuhnya lebih kecil, sedangkan ternak yang genetiknya lebih baik (tubuh lebih besar) dijual untuk mendapat nilai jual yang lebih besar. Hal ini menyebabkan terkurasnya sumber daya genetik sapi Pesisir dari tahun ke tahun, sehingga ternak yang tersisa adalah ternak yang pertumbuhan lambat yang tercermin dengan rendahnya bobot badan. Penelitian Saladin (1983) melaporkan rata-rata berat badan sapi Pesisir jantan dewasa (umur 4-6 tahun) $294 \mathrm{~kg}$ sedangkan penelitian Sarbaini (2004) melaporkan rata-rata berat badan jantan dewasa $162 \mathrm{~kg}$, jadi telah terjadi penurunan berat badan yang sangat besar selama 20 tahun terakhir. Untuk meningkatkan performance sapi pesisir seleksi yang tepat harus dilakukan, seleksi berdasarkan record ternak sulit dilakukan kerena record produksi sapi Pesisir sulit diperoleh, dan juga akan membutuhkan waktu yang lama dalam pelaksanaanya.Teknologi terakhir telah memungkinkan untuk meningkatkan ketepatan dan efesiensi seleksi melalui seleksi berbantuan gen (Gen Assisted Selection atau GAS) atau seleksi berbantuan marka (Marker Assisted Selection atau MAS). Namun demikian, penerapan dengan menggunakan pendekatan MAS memerlukan suatu identifikasi penciri gen kandidat (candidate gene). Salah satu gen yang diketahui sangat berperan dalam pertumbuhan seekor ternak sapi adalah gen hormon pertumbuhan (bGH). Untuk menimbulkan efeknya GH harus terikat pada reseptornya (GHR). Suatu penciri genetik molekuler dikatakan sebagai gen kandidat apabila nyata pengaruhnya secara biologis pada sifat-sifat kuantitatif (Park, 2004), dan salah satu gen yang dianggap sebagai gen kandidat pada pertumbuhan adalah gen hormon pertumbuhan atau bGH (Unanian, et al.,1994) dan GHR (Ge et al., 2003).

Gen GHR pada sapi berada pada chromosome 20 terdiri atas 10 exon dan 9 intron yang meliputi mempunyai panjang sekuen 365.186 bp. Ge et al., (2000) mendapatkan 4 polimorfisme pada exon 10 , yaitu $\mathrm{C}$ menjadi T pada posisi $76 \mathrm{bp}$, A menjadi $\mathrm{G}$ pada posisi 200, C menjadi T pada posisi 229 , dan A menjadi $G$ pada posisi 257. Menurut Ge et al., (2003) polimorfisme ini dapat dideteksi dengan mengunakan enzyme MaeII (Boehringer Mannheim, Indianapolis IN), NarI (Promega Co., Madison, WI), NlaIII (Biolabs, Beverly, MA), AluI (Promega).

Blott et al., (2003) mendapatkan adanya hubungan antara gene GHR dengan komposisi susu sapi Holstein-Friesian, sedangkan Viitala et. al., (2006) mendapatkan adanya hubungan polimorfisme gen GHR dengan produksi susu sapi Finnish Ayrshire. Sedangkan Sherman et al., (2008) mendapatkan hubungan yang sangat nyata antara SNP pada intron 4 dari GHR dengan berat lahir dan efesiensi makanan pada sapi.

Beberapa SNP pada gen GHR sapi telah dilaporkan berhubungan dengan level serum IGF1, berat karkas, lean cuts, prosentase berat karkas segar, dan drip loss (Ge et al., 2003; Maj et al., 2004, 2006, Di Stasio et al., 2005). Selanjutnya Ge et al., (2003) mendapatkan polimorfisme pada exon 10 sangat berhubungan dengan konsentrasi IGF1 darah. Blott et al. (2003) mendapatkan adanya variasi gen GHR pada exon 8 yang menyebabkan terjadi perobahan $\mathrm{T}$ menjadi A yang menghasilkan perobahan phenylalanine (GHR279F) menjadi 
tyrosine (GHR279Y) dimana sapi yang membawa GHR279Y produksinya lebih tinggi dari GHR279F. Selanjutnya Blott et al., (2003) juga mendapatkan keragamn sekuen ini berpengaruh terhadap berat ternak, ukuran dewasa tubuh ternak. Menurut Ge et al., (2003) gen GH dan GHR adalah kandidate gen penting yang dapat digunakan sebagai penanda genetik untuk sifat pertumbuhan, karkas, dan produksi susu pada ternak.

\section{METODE}

Data penelitian ini berasal dari data penelitian lapangan dan penelitian laboratorium. Penelitian lapangan untuk memperoleh data karakter eksternal (berat badan dan ukuran-ukuran tubuh) dan penelitian laboratorium untuk memperoleh data polimorfisme dan sekuen gen reseptor hormone pertumbuhan. Penelitian lapangan dilaksanakan di Kabupaten Pesisir Selatan yaitu pada Kecamatan Ranah Pesisir, Kecamatan Lengayang dan Kecamatan Sari Linggo baganti. Penelitian lapangan ini dilakukan dari bulan Maret sampai Mei 2010.Sampel ternak adalah sapi yang berumur $\pm 1,5$ tahun dengan kelamin jantan. Penentuan umur ternak sapi sampel dilakukan berdasarkan pada keterangan langsung dari peternak dan pertukaran gigi seri menurut klassifikasi $I_{1}$ sudah haus atau mulai berganti. Jumlah sample ternak sapi 216 ekor yaitu 72 ekor pada masing-masing kecamatan, dari 216 ekor sample akan dipilih 60 ekor sapi dengan ketentuan 30 ekor dengan berat badan rendah dan 30 ekor dengan berat badan paling tinggi.Penelitian di laboratorium dilakukan untuk menganalisis variasi fragmen-fragmen gen reseptor hormon per-tumbuhan pada exon 10 dan sekuensing fragmen spesifik.

\section{Isolasi DNA Total}

Isolasi DNA Genomik dari Darah Sapi dilakukan dengan menggunakan protokol Genomik DNA Purification Kit dari Promega.

\section{Amplifikasi Exon 10 Gen Reseptor Hormon Pertumbuhan}

Setelah DNA diisolasi maka akan diamplikasi dengan menggunakan dua pasang pri- mer yaitu 5'- TCCAAGTTCATTGGCAAAC -3' dan 5'-TGATTCAGCCTCAACATGAG3' dan pasangan primer 5'-CTGGGGCATGA ATGCTTAAA-3' dan 5'- GCACAAAATTA ACACCCACAA -3'yang akan mengamplikasi sekuen sepanjang 232 dan 240bp. Prosedur amplikasi PCR menggunakan pure Tag Ready-To-Go PCR dari GE Healthcare (USA). Untuk setiap tabung reaksi ditambahkan $2 \mu \mathrm{l}$ (20 ng) genomic DNA, $2 \mu \mathrm{l}(20 \mathrm{nM})$ maing-

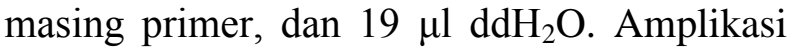
dilakukan dengan 40 siklus dengan denaturasi awal $96^{\circ} \mathrm{C}$ selama 5 menit, $94^{\circ} \mathrm{C}$ selama 60 detik, $60^{\circ} \mathrm{C}$ selama 90 detik, dan $72^{\circ} \mathrm{C}$ selama 80 detik, dan dikuti dengan 5 menit pada temperature $72^{\circ} \mathrm{C}$. Untuk melihat hasil amplikasi dilakukan elektroforesis dengan agarose $1,0 \%$, diwarnai dengan Ethidium Bromide dan dievaluasi dengan menggunakan UV transluminator. Produk PCR menggunakan pasangan primer GHR1L dan GHR1R di sekuensing digestilasi,sedangkan produk PCR menggunakan pasangan primer GHR2L dan GHR2R akan digestilasi menggunakan enzim NlaIII.

\section{Gel Purifikasi.}

Jika fragmen hasil amplifikasi PCR tidak spesifik gel yang berisikan fragmen target diisolasi dari gel agarose dengan pemotongan menggunakan scalpet steril, dan difurifikasi menggunakan kit-gel purifikasi (Promega-USA).

\section{Analisis Data}

Frekunsi alel gen GHR yang diperoleh dari analisis penciri PCR-RFLP dihitung menggunakan rumus (Nei, 1987).

$$
x_{i}=\frac{\left(2 n_{i j}+\sum_{j \neq i} n_{i j}\right)}{2 n}
$$

$x_{i}=$ frekuensi alel ke i

$n_{i i}=$ jumlah individu bergenotip $\mathrm{A}_{\mathrm{i}} \mathrm{A}_{\mathrm{i}}$

$n_{i j}=$ jumlah individu bergenotip $\mathrm{A}_{\mathrm{i}} \mathrm{A}_{\mathrm{j}}$

$\boldsymbol{n}=$ jumlah sampel total

Keseimbangan Hardy-Weinberg diuji dengan Chi-square $\left(\chi^{2}\right)$ 


$$
H W=\sum \frac{\left(O_{i}-E_{i}\right)}{E_{i}}
$$

Untuk menguji apakah ada hubungan antaravariasi sekuen dengan dengan berat badan dibuat table kontingensi antara keduanya kemudian diuji dengan uji $\chi 2$;

$$
\chi^{2}=\sum \sum \frac{\left(O_{i j}-E_{i j}\right)}{E_{i j}}
$$

Keterangan : $\mathrm{Oi}=$ nilai observasi ke I $\mathrm{Ei}=$ nilai harapan ke $\mathrm{i}$.

\section{HASIL DAN PEMBAHASAN}

Rata-rata Berat Badan, Panjang Badan, Lingkat Dada dan Tinggi Pundak Sapi Pesisir Umur 1,5 tahun.

Rata-rata berat badan sapi pesisir umur 1,5 tahun adalah $98 \pm 23,42 \mathrm{~kg}$. Sedangkan rata berat sampel terpilih untuk kelompok berat badan rendah adalah $63,46 \pm 6,69 \mathrm{~kg}$ dan ratarata berat badan untuk kelompok badan tinggi adalah $131,5 \pm 13 \mathrm{~kg}$. Dari data berat badan ini terlihat sangat bervariatif sekali yang terlihat besarnya standard deviasi sampel $(23,42 \mathrm{~kg})$ sehingga sangat terbuka peluang untuk melakukan seleksi pada sapi pesisir terkait bobot badan. Rataan bobot badan ini tidak jauh berbeda dengan penelitian Sarbaini (2004) yang memperoleh rata-rata bobot anak sapi $84.4 \pm 16.0 \mathrm{~kg}$ dan bobot badan sapi muda $124.4 \pm 23.6 \mathrm{~kg}$.

\section{Isolasi DNA Total}

Isolasi DNA Genomik dari Darah Sapi dengan menggunakan protokol Genomik DNA Purification Kit dari Promega memberikan hasil yang yang cukup memadai dengan konsentrasi DNA cukup tinggi yaitu antara $200-500 \mathrm{ng}$ $/ \mu 1$ (Gambar 1). Dengan hasil ini membuktikan Genomik DNA Purification Kit dari Promega cukup handal untuk mengisolasi DNA genomik sapi.

\section{Amplifikasi Exon 10 Gen Reseptor Hormon Pertumbuhan}

Setelah DNA diisolasi maka diamplikasi dengan menggunakan dua pasang primer yang diharapkan (GHR1 dan GHR 2) pada Gambar 2 dan 3, dengan annealing $60^{\circ} \mathrm{C}$. Setelah diimplikasi semua produk PCR di elektroforesis, kemudian gel dipotong untuk dilakukan purifikasi untuk selanjutnya dilakukan restriksi dengan enzime NlaIII. Sedangkan produk PCR dari pasangan primer GHR1 selanjutnya di sekuensing.

\section{Frekuensi Genotipe, Alel dan keseimbang- an Hardy-Weinberg}

Analisis gen reseptor hormon pertumbuhan pada sapi Pesisir untuk penciri PCRRFLP NlaIII diperoleh dua macam genotipe yaitu genotipe CC (satupita yaitu $240 \mathrm{bp}$ ), TT ( dua pita yaitu 79, dan161 bp (Gambar 4). Posisi penciri gen GHR NlaIII yang terletak pada intron 10 dengan panjang produk $240 \mathrm{bp}$ yang diduga berdasarkan sekuen gen GHR (Viitala, et al., 2006). Gambaran sekuen dan posisi atau situs pemotong enzim NlaIII disajikan pada Gambar 4 dan Gambar 5. Frekuensi genotipe dan allel penciri PCRRFLP NlaIII untuk genotipe CC dan TT masing-masing 0,967 dan 0,033. Nei (1987) menyatakan bahwa suatu alel dikatakan polimorfik jika memiliki frekuensi alel sama dengan atau kurang dari 0,99 (99\%) atau

\section{$\begin{array}{lllllllllllll}\mathrm{S} 01 & \mathrm{S02} & \mathrm{S} 03 & \mathrm{~S} 04 & \mathrm{M} & \mathrm{S} 05 & \mathrm{~S} 06 & \mathrm{~S} 07 & \mathrm{~S} 0 \mathrm{~S} & \mathrm{~S} 09 & \mathrm{~S} 10 & \mathrm{~S} 11 & \mathrm{~S} 12\end{array}$}

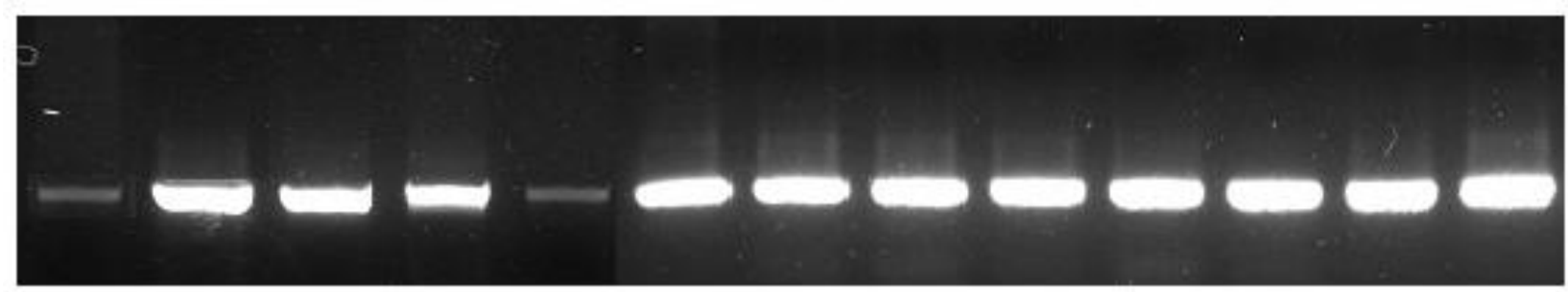

Gambar 1. Elektroforesis DNA total hasil isolasi menggunakan Genomik DNAPurification Kit dari Promega. $\mathrm{M}=$ marker $25 \mathrm{ng} / \mu \mathrm{l}, \mathrm{S} 1-\mathrm{S} 15=$ sampel individu 


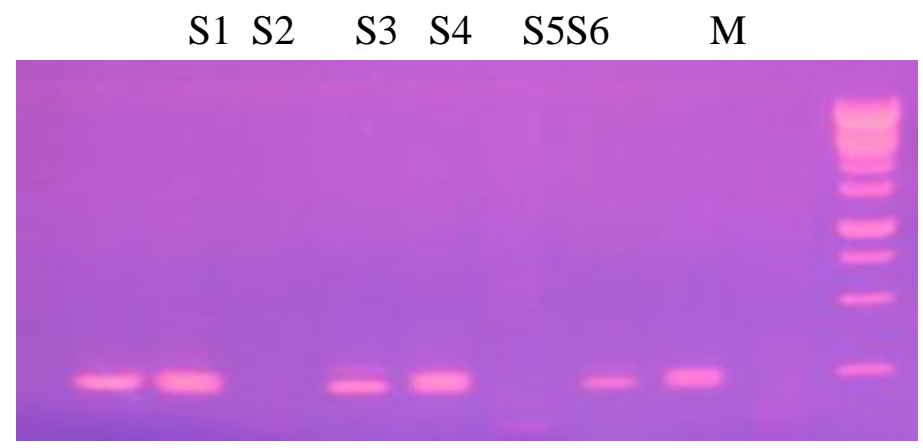

Gambar 2. Elektroforesis produk PCR-RFLP gen reseptor hormon pertumbuhan menggunakan primer GHR 1. M=marker, S1-S6 = sampel individu

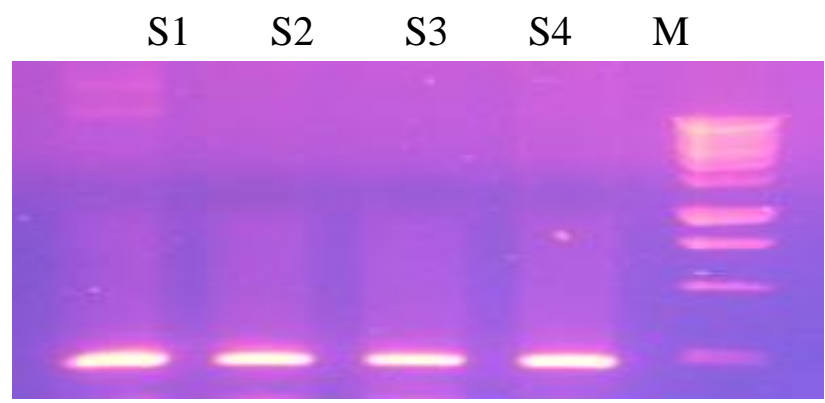

Gambar 3. Elektroforesis produk PCR-RFLP gen reseptor hormon pertumbuhan menggunakan primer GHR 2. M=marker, S1-S4 = sampel individu

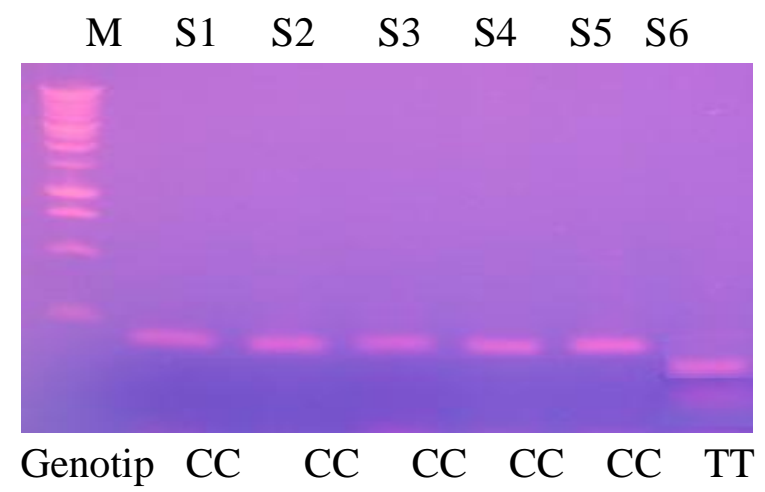

Gambar 4. Elektroforesis produk PCR-RFLP gen reseptor hormon pertumbuhan menggunakan enzim pemotong NlaIII. $\mathrm{M}=$ marker, $\mathrm{S} 1-\mathrm{S} 6=$ sampel individu

$\rightarrow$ Primer Forward

$$
\begin{aligned}
& \text {.....5'ctggggcatgaatgettaaaccaaaacaatgtttaaactt } \\
& \text { tttttgggaggggggtgagttgagggtggggaatatg*aattct } \\
& \text { aaatgccttttctgaaatgttgaaacattaaaaaaagaagaag } \\
& \text { aatccttaatcagataaatattgctgttgtgaattgtaaatact } \\
& \text { ttaaagaactgtctcaaagactgtttagtggcagtaattgtctt } \\
& \text { gttattgtgggtgttaattttgtgc } 3 \text {, }
\end{aligned}
$$

\section{$\leftarrow$ Primer Reverse}

Gambar 5. Sekuen fragmen gen GHR NlaIII dan situs pemotongnya pada posisi intron10.(Viitala, et al., 2006). Panjang sekuen 240bp, tatg* $=$ situs pemotongan enzime NlaIII jika terjadi mutasi $\mathrm{t} \rightarrow \mathrm{c}$ 
Tabel 1. Polimorphis fragman gen GHR hasil dengan pasangan primer GHR11 dan GHR1R

\begin{tabular}{cccc}
\hline No. & Mutasi & Posisi nucleotida & $\begin{array}{c}\text { Frekuensi } \\
\text { Allel }\end{array}$ \\
\hline 1 & T $\rightarrow$ C & 32 & 0,50 \\
2 & Delesi TAA & 34 & 0,45 \\
3 & Delesi T & 39 & 0,15 \\
4 & Delesi T & 45 & 0,46 \\
5 & G $\rightarrow$ A & 50 & 0,23 \\
6 & Delesi G & 50 & 0,46 \\
7 & Insersi T & 67 & 0,19 \\
8 & Insersi A & 74 & 0,19 \\
9 & A $\rightarrow$ C & 109 & 0,19 \\
10 & Insersi G & 113 & 0,25 \\
11 & Dilesi TATTA & 115 & 1,00 \\
12 & Insersi G & 133 & 0,45 \\
13 & G $\rightarrow$ C & 150 & 1,00 \\
14 & G $\rightarrow$ C & 199 & 0,60 \\
\hline
\end{tabular}

dengan kata lain suatu alel dikatakan monomorfik jika frekuensi alel sama dengan atau kurang dari $0,01(1 \%)$. Genotipe TT pada penciri PCR-RFLP NlaIII merupakan genotipe yang terjadi karena adanya mutasi pada situs pemotong enzim NlaIII (tatg*) dimana terjadi mutasi $\mathrm{c} \rightarrow \mathrm{t}$, dengan demikian sapi Pesisir umumnya tidak mengalami mutasi pada gen reseptor hormon pertumbuhan terutama di situs pemotong enzim NlaIII karena sebagian besar sapi Pesisir bergenotipe CC (Gambar 5). Menggunakan sekuen Viitala et al., (2006) sebagai dasar analisis terlihat fragmen GHR 1 sangat polimorpic dimana ditemui adanya 13 keragaman (Tabel1). Lima dilesi terdeteksi pada posisi 34, 39, 45, 50, dan 115 dengan frekuensi allel masing-masing $0,45,0,15$, 0,46, 0,46, dan 1,00 dan 4 insersi terdeteksi yaitu insersi $\mathrm{T}$ pada posisi 67 , insersi A pada posisi 74 , insersi $G$ pada posisi 113 , insersi $G$ pada posisi 113, and insersi Gin posisi 133 dengan frekuensi allel berturut-turut 0,19 , $0,19,0,25$, dan 0,45 . Lima mutasi terdeteksi yaitu pada posisi $32,50,109$, and 150 dengan genotip $\mathrm{T} \rightarrow \mathrm{C}, \mathrm{G} \rightarrow \mathrm{A}, \mathrm{A} \rightarrow \mathrm{C}$ dan $\mathrm{G} \rightarrow \mathrm{C}$ dengan frekuensi allel berturut-turut 0,50, $0,23,0,19,1,00$ dan 0,60 . Suatu populasi dinyatakan dalam keseimbangan Hardy Weinberg, jika frekuensi genotipe (p2, 2pq dan $q 2$ ) dan frekuensi alel ( $p$ dan $q$ ) konstan dari generasi ke generasi, karena akibat penggabungan gamet yang terjadi secara acak. Hasil uji chi-square (X2) terhadap penciri PCR-RFLP NlaIII menunjukkan frekuensi genotipe tidak seimbang $(\mathrm{P}>0,05)$ yang berarti pada populasi sapi Pesisir tidak terjadi kawin acak, adanya seleksi, mutasi, migrasi dan terjadi endogami. Menurut Vasconcellos et al. (2003) beberapa kejadian seperti akumulasi genotipe, populasi yang terbagi, mutasi, seleksi, migrasi dan perkawinan dalam kelompok/populasi yang sama (endogami) dapat menimbulkan ketidakseimbangan dalam populasi. Hasil analisis statistika menunjukkan tidak adanya hubungan antara bobot badan dengan penciri PCR-RFLP NlaIII. Hal ini disebabkan bobot badan dan ukuran-ukuran tubuh sangat dipengaruhi lingkungan seperti makanan dan sistim pemeliharaan sedangkan sampel diambil dari sapi rakyat yang sistim pemeliharaan nya relatif tidak seragam.

\section{KESIMPULAN}

Sapi Pesisir umumnya memiliki keragaman berat badan dan keragaman genetic yang sangat tinggi, sehingga sapi pesisir sangat berpeluang ditingkatkan berat hidupnya. Frekuensi alel $\mathrm{C}(0,967)$ yang lebih tinggi 
dibandingkan dengan alel $\mathrm{T}(0,033)$ untuk penciri PCR-RFLP NlaIII. Hasil analisis terhadap gen reseptor hormon pertumbuhan pada sapi Pesisir juga mengindikasikan bahwa penciri molekuler PCR-RFLP NlaIII bersifat monomorfik. Tidak ada hubungan antara bobot hidup dan ukuran-ukuran tubuh dengan penciri molekuler.

\section{DAFTAR PUSTAKA}

Blott, S., J. J. Kim, S. Moisio, A. SchmidtKuntzel, A. Cornet, P. Berzi, N. Cambisano, C. Ford, B. Grisart, D. Johnson, L. Karim, P. Simon, R. Snell, R. Spelman, J. Wong, J. Vilkki, M. Georges, F. Farnir, and W. Coppieters. 2003. Molecular dissection of a quantitative trait locus: A phenylalanineto-tyrosine substitution in the transmembrane domain of the bovine growth hormone receptor is associated with a major effect on milk yield and composition. Genetics 163:253-266.

Di Stasio, L., G. Destefanis, A. Brugiapaglia, A. Albera, and A. Rolando. 2005. Polymorphism of the GHR gene in cattle and relationships with meat production and quality. Anim. Genet. 36:138-140.

Ge, W., M. E. Davis, H. C. Hines, K. M. Irvin, and R. C. Simmen. 2003. Association of single nucleotide polymorphisms in the growth hormone and growth hormone receptor genes with blood serum insulinlike growth factor I concentration and growth traits in Angus cattle. J. Anim. Sci. 81:641-648

Maj, A., J. Oprzadek, A. Oprzadek, E. Dymnicki and L. Zwierzchowski. 2004. Polymorphism in the 5'-noncoding region of the bovine growth hormone receptor gene and its association with meat production traits in cattle. Anim. Res. 53:503-514.

Maj, A., J. Oprzadek, E. Dymnicki, and L. Zwierzchowski. 2006. Association of the polymorphism in the 5 '-noncoding region of the bovine growth hormone receptor gene with meat production traits in polish black-and-white cattle. Meat Sci. 72:539-544.

Nei M. 1987. Molecular Evolutionary Genetics. Columbia University Press. New York.

Park, H. B. 2004. Genetic analysis of quantitative traits using domestic animals: A Candidate Gen and Genome Scanning Approach Dissertation Uppsala University. Sweden.

Saladin, R. 1983. Penampilan sifat-sifat produksi dan reproduksi sapi lokal Pesisir Selatan di Provinsi Sumatera Barat. Disertasi. Fakultas Pascasarjana IPB. Bogor.

Sarbaini, A. 2004. Kajian keragaman karakteristik eksternal dan DNA mikrosatelit sapi Pesisir Sumatera Barat. Disertasi Sekolah Pascasarjana IPB. Bogor.

Sherman, E. L., J. D. Nkrumah, B. M. Murdoch, C. Li, Z. Wang, A. Fu, and S. S. Moore. 2008. Polymorphisms and haplotypes in the bovine neuropeptide $\mathrm{Y}$, growth hormone receptor, ghrelin, insulin-like growth factor 2, and uncoupling proteins 2 and 3 genes and their associations with measures of growth, performance, feed efficiency, and carcass merit in beef cattle. J. Anim. Sci. 86:1-16.

Unanian, M. M., S. K. DeNise, H. M. Zhang. R. L. A. 1994. Rapid communication polymerase chain reaction-restriction fragment length polymorphism in the bovine growth hormone gen. J. Anim. Sci., 72:2203

Vasconcellos, L. P. M. K., D. T. Talhari, A. P. Pereira, L. L. Coutinho and L. C. A. Regitano. 2003. Genetic characterization of Aberdeen Angus cattle using molecular markers. Genetic and Molecular Biology 26:133-137.

Viitala, S., J. Szyda, S. Blott, N. Schulman, M. Lidauer, A. Ma“ki-Tanila, M. Georges and J. Vilkki. 2006. The Role 
of the bovine growth hormone receptor and prolactin receptor genes in milk, fat and protein production in finnish ayrshire dairy cattle. Genetics 105.2006.

Genetics 173: 2151-2164. 